\title{
ANALISIS SUPERVISI KLINIS KEPALA SEKOLAH DI SEKOLAH MENENGAH PERTAMA ISLAM TERPADU PONDOK PESANTREN RAUDHATUL ULUM SAKATIGA INDRALAYA OGAN ILIR
}

\author{
Sefri Kandi Ja'far Yazid \\ Sekolah Tinggi Ilmu Tarbiyah Raudhatul Ulum Sakatiga \\ Email: sefrikandi@stit-ru.ac.id
}

\begin{abstract}
Abstrak
This journal is entitled "Analysis of the Competency Analysis of the Principal's Clinical Supervision in Islamic Middle School Integrated Islamic Boarding School Raudhatul Ulum Sakatiga Indralaya Ogan Ilir". The main concern of education supervision is the problem of teaching quality and improvement efforts, and refers to the main mission of educational organizations, namely activities aimed at improving and improving academic quality. In other words, educational supervision is an activity that deals with the improvement, improvement of the process and learning outcomes. In the implementation of supervision at Raudhatul Ulum Sakatiga Middle School, the headmaster has conducted supervision activities, despite the assumption from teachers that the supervision activities are carried out to look for mistakes, but actually contain more coaching elements, so that the working conditions that are being supervised can be known for their shortcomings (not solely its error) to be told which part needs to be fixed. And become a tool for teachers to become more professional in teaching. The data source in this study consisted of primary data sources (school principals, curriculum chiefs and Raudhatul Ulum Junior High School IT teachers) and secondary data sources namely all supporting documents and data. Data collection techniques used are observation, documentation and interviews. While the data analysis technique used is descriptive qualitative by means of data reduction (summarizing and selecting the main points), data display (presenting data in a brief pattern), data verification (drawing conclusions temporarily). The research results obtained as follows: Supervision competencies conducted at Raudhatul Ulum Sakatiga Middle School IT have run well in accordance with the objectives. Supervision competencies in accordance with the principles, techniques, approaches and follow-up from the results of supervision conducted
\end{abstract}

Kata Kunci: Supervision Comptence, Principal

\section{Pendahuluan}

Secara konseptual, tanggungjawab atas penyelenggaraan pendidikan adalah kepala sekolah, kepala sekolah bertanggung jawab atas pengelolaan pendidikan secara mikro, kepala sekolah memimpin lembaga dengan peranan yang sangat besar bagi peningkatan kemajuan sekolah, hal ini dikarenakan tugas kepala sekolah dalam mengawasi kegiatan yang telah diprogramkan agar mmenjadi terarah, terfokus dan berhasil dengan baik. Kompetensi supervisi harus menjadi bagian penting bagi 
Analisis Supervisi Klinis Kepala Sekolah di Sekolah Menengah Pertama Islam Terpadu Pondok Pesantren Raudhatul Ulum Sakatiga Indralaya Ogan Ilir Safri Kandi Ja'far Yazid

kepala sekolah sebab supervisi merupakan upaya meningkatkan prestasi belajardan mutu sekolah.

Sementara M. Amin Thaib, et al., menyatakan bahwa supervisi merupakan istilah dari bahasa Inggris "Super" dan "vision". Super berarti luar biasa, istimewa, sedangkan vision yang brarti kemampuan untuk melihat pada persoalan. Jadi supervisi berarti kemampuan seseorang untuk melihat pada suatu persoalan (pelaksanaan tugas) seseorang sampai pada inti persoalan yang dihadapinya (Thaib, et.al, 2005: 7).

Supervisi pendidikan sendiri merupakan usaha meningkatkan kompetensi dan kemampuan professional guru dalam upaya mewujudkan proses pembelajaran yang lebih baik melalui cara-cara mengajar yang lebih baik yang akhirnya berdampak kepada peningkatan hasil belajar peserta didik (Thaib, et.al, 2005: 19). Senada dengan yang dikemukakan Ibrahim Bafadal menyatakan bahwa supervisi dapat diartikan sebagai layanan profesional.Layanan profesional tersebut berbentuk pemberian bantuan kepada personal sekolah dalam meningkatkan kemampuannya sehingga lebih mampu mempertahankan dan melakukan perubahan penyelenggaraan sekolah dalam rangka meningkakan pencapaian tujuan sekolah. Layanan profesional itu dapat juga berupa membantu guru meningkatkan kemampuannya dalam mengelola proses belajar mengajar dalam rangka pencapaian tujuan sekolah. Supervisi pendidikan pada hakikatnya adalah serangakaian kegiatan membantu personal meningkatkan kemampuannya (Bafadal, 2005: 72). Oleh karenanya supervisi pendidikan mempunyai peran penting dalam upaya peningkatan kompetensi dan kemampuan professional guru.

Zainal Aqib dan Elham Rohmanto, bahwa tujuan supervisi untuk memperbaiki tujuan pembelajaran, memperbaiki bahan ajar, memperbaiki pendekatan, model, metode, teknik pembelajaran, memperbaiki pembimbing siswa, dan memperbaiki sikap guru (Aqib, Rohmanto, 2008: 201). Selanjutnya Subari mengungkapkan bahwa tujuan atau tugas pokok supervisor adalah menolong guru agar mampu melihat persoalan yang dihadapi.Sedangkan tujuan supervisinya adalah untuk mengembangkan situasi pemeblajaran yang lebih baik melalui pembinaan dan peningkatan profesi mengajar (Suryobroto, 2004: 175). Atau kata kunci supervisi adalah memberikan layanan dan bantuan kepada guru-guru, maka tujuan supervisi adalah memberikan layanan dan bantuan untuk mengembangkan situasi pembelajaran yang dilakukan guru di kelas (Sahertian, 2006: 19).

Dari berbagai pengertian tujuan supervisi pendidikan di atas, dapat dimaknai bahwa pelaksanaan supervisi pada hakikatnya bertujuan untuk membantu guru mengembangkan situasi belajar mengajar kearah yang lebih baik, yang ditandai dengan meningkatnya efektifitas dan efisiensi belajar mengajar, penyelenggaraan bidang teknis edukatif di sekolah sesuai dengan ketentuan-ketentuan dan kebijakan yang telah ditetapkan, kegiatan berlangsung sesuai dengan ketentuan yang berlaku, sehingga berjalan lancar dan memperoleh hasi optimal. 
Kemajuan sekolah banyak dipengaruhi oleh kepala sekolah sebagai pemimpin pendidikan. Oleh Karen itu kepala sekolah dalam menjalankan tugasnya harus mempunyai kemampuan-kemampuan yang mendasar. Kemampuan-kemampuan itu adalah kompetensi kepala sekolah. Kompetensi kepala sekolah adalah seperangkat pengetahuan, keterampilan, dan prilaku yang dihayati serta dikuasai dalam menjalankan tugasnya.

Menurut Peraturan Menteri Pendidikan Nasional Nomor 13 Tahun 2007 Tanggal 17 April 2007 Tentang Standar Kepala Sekolah/Madrasah dinyatakan sebagai berikut:

"Kepala Sekolah harus memiliki lima kompetensi yaitu: kepribadian, manajerial, kewirausahaan, supervisi, dan sosial. Kompetensi kepribadian menyangkut integritas dan kejujuran. Kompetensi manajerial yang terkait kemampuan kepala sekolah mengelola sekolah dan sumberdaya yang ada disekolah. Kompetensi supervisi meliputi: 1. Merencanakan program supervisi akademik dalam peningkatan profesionalisme guru, 2. Melaksanakan supervisi akademik terhadap guru dengan menggunakan pendekatan dan teknik supervisi yang tepat, dan 3. Menindak lanjuti hasil supervisi akademik terhadap guru dalam rangka peningkatan profesionalisme guru". (Sisdiknas, 2003: 225-227).

Dari berbagai peraturan dapat dimengerti bahwa pelaksanaan supervisi oleh kepala sekolah akan sangat berpengaruh terhadap proses pembelajaran di kelas, karena salah satu tujuan supervisi kepala sekolah adalah untuk memperbaiki kinerja guru dalam proses pembelajaran, oleh karena itu dalam pelaksanaan supervisi akan melalui berbagai proses dalam pelaksanaannya, seperti proses; a. Persiapan, b. Pelaksanaan supervisi, dan c. Tindak lanjut, senada dengan Ali Imron, secara umum proses pelaksanaan supervisi dilaksanakan melalui tiga tahapan yaitu perencanaan, pelaksanaan, dan tindak lanjut (Imran, 2004: 53).

Standar kepala sekolah/madrasah dalam Peraturan Menteri Pendidikan Nasional Nomor 13 Tahun 2007 dan tujuan supervisi pendidikan yang sesungguhnya, sebagaimana yang telah diungkap oleh Daryanto dan M Farid,tujuan supervisi adalah mengembangkan situasi belajar dan belajar yang lebih baik dan efektif (Daryanto, 2013: 184). Sedangkan Piet A Sahertian menyatakan tujuan supervisi pendidikanadalah memberikan layanan dan bantuan untuk mengembangkan situasi belajar mengajar yang dilakukan guru di kelas (Sahertian, 2006: 19). Dengan demikian jelas bahwa tujuan supervisi memberikan layanan dan bantuan untuk meningkatkan kualitas mengajar guru atau keprofesesionalitas guru di kelas yang pada dasarnya untuk meningkatkan kualitas belajar siswa.Bukan saja memperbaiki kemampuan mengajar tapi juga untuk pengembangan potensi kualitas guru.

Dari penjelasan di atas dapat diartikan kegiatan supervisi bukan mencari-cari kesalahan tetapi lebih banyak mengandung unsur pembinaan, agar kondisi 
Analisis Supervisi Klinis Kepala Sekolah di Sekolah Menengah Pertama Islam Terpadu Pondok Pesantren Raudhatul Ulum Sakatiga Indralaya Ogan Ilir

Safri Kandi Ja'far Yazid

pekerjaan yang sedang disupervisi dapat diketahui kekurangannya (bukan semata mata kesalahannya) untuk dapat diberitahu bagian yang perlu diperbaiki.

\section{Metode Penelitian}

Metode penelitian adalah cara-cara yang dapat digunakan oleh peneliti untuk mengumpulkan data (Arikunto, 2010: 100). Sedangkan menurut Beni Ahmad Saebani, metode penelitian adalah metode yang digunakan dalam aktivitas penelitian (Saebani, 2008: 43). Dalam hal ini, data-data penelitian ini dikumpulkan dengan metode observasi, wawancara, dokumentasi.Selanjutnya data dianalisis dengan menggunakan metode analisis deskriptif kualitatif yaitu mendeskripsikan data yang dikumpulkan berupa kata-kata.

Dibawah ini peneliti akan menjelaskan metode-metode yang akan peneliti pergunakan:

1. Jenis Penelitian

Adapun jenis penelitian yang digunakan adalah penelitian kualitatif. Dengan pendekatan penelitian deskriptif kualitatif. Penelitian deskiriptif merupakan penelitian yang dimaksudkan untuk mengumpulkan informasi mengenai gejalagejala yang ada, yaitu keadaan gejala menurut apaadanya pada saat penelitian (Arikunto, 2010: 234). Sedangkan kualitatif adalah penelitian yang analisis isi lebih penting daripada frekuensi atau bilangan (Sudjana, 2012: 129). Penelitian kualitatif menurut Denzin dan Loncoln, adalah penelitian yang menggunakan latar ilmiah, dengan maksud menafsirkan fenomena yang terjadi dan dilakukan dengan jalan melibatkan berbagai metode yang ada (Tohirin, 2012: 2).

\section{Sumber Data}

Dalam penelitian kualitatif tidak menggunakan istilah populasi, tetapi dinamakan "social situation" atau situasi sosial yang terdiri atas tiga elemen yaitu; tempat (place), pelaku (actors), dan aktivitas (activity) yang berinteraksi secara sinergis (Sugiyono, 2013: 215). Dengan uraian sebagai berikut, tempat (place): tempat penelitian di SMP IT Raudhatul Ulum, pelaku (actors): kepala sekolah dan guru SMP IT Raudhatul Ulum, aktivitas (activity): supervisi kepala sekolah dan profesionalitas guru SMP IT Raudhatul Ulum.

Dalam penelitian ini, sampel sumber data dipilih dengan teknik purposive sampling. Menurut Suharsimi Arikunto teknik purposive sampling adalah teknik penarikan narasumber penelitian dengan cara mengambil subjek bukan didasarkan atas adanya tujuan tertentu.

3. Teknik pengumpulan data

Sesuai dengan penelitian yang menggunakan pendekatan kualitatif, juga relevensinya dengan rumusan masalah dan tujuan penelitian maka metode dalam pengumpulan data dilakukan melalui teknik observasi, wawancara dan dokumentasi. 
P-ISSN : 2541-3686

\section{a. Metode Observasi}

Metode observasi ini, merupakan suatu metode pengumpulan data, dengan cara pengamatan dan pencatatan secara sistematis, mengenai fenomena yang diselidiki (Arikunto, 2010: 133). Metode observasi merupakan sebuah teknik pengumpulan data yang mengharuskan peneliti turun ke lapangan mengamati halhal yang berkaitan dengan ruang, tempat, pelaku, kegiatan, benda-benda, waktu, peristiwa, tujuan, dan perasaan (Al-Mansur, 2012: 165). Dalam penelitian ini peneliti menggunakan observasi partisipatif dan bersifat partisipatif pasif ((Sugiyono,. 2013: 233).

\section{b. Metode Wawancara}

Wawancara adalah proses tanyajawab dalam penelitian yang berlangsung secara lisan dalam mana dua orang atau lebih bertatap muka mendengarkan secara langsung informasi-informasi atau keterangan-keterangan (Narbuko dan Achmadi, 2012: 83). Metode inidigunakan dengan wawancara tidak berstruktur(unstructured interview)yaitu wawancara yang bebas dimana peneliti tidak menggunakan pedoman wawancara yang telah tersusun secara sistematis dan lengkap untuk pengumpulan datanya. Pedoman wawancara yang digunakan hanya berupa garisgaris besar permasalahan yang akan ditanyakan(Sugiyono,. 2013: 233-234). Hal ini digunakan agar bersifat lebih terbuka untuk mendorong subjek penelitian menjawab lebih lengkap sesuai dengan tujuan penelitian.

\section{c. Metode Dokumentasi}

Metode ini digunakan untuk memperoleh catatan, transkrip, buku, suratkabar, data dan sebagainya (Arikunto, 2006: 274). Jadi metode ini, adalah metode pengumpulan data dengan cara mencari informasi, melalui dokumentasi, arsiparsip, buku-buku catatan dan lainnya terkait dengan data yang dibutuhkan seperti yang diungkap di atas, yaitu bagi kepala sekolah, adalah rencana program supervisi kepala sekolah, dokumen pelaksanaan supervisi (instrument hasil supervisi) kepala sekolah bagi guru, penelusuran silabus dan rencana pelaksanaan pembelajaran.

\section{Teknik Analisis Data}

Analisis data merupakan proses penyusunan data agar dapat diinterprentasi. Analisis data penelitian ini bermanfaat untuk memecahkan masalah penelitian dan mencapai tujuan akhir penelitian (Subagyo, 2006: 105). Pola analisis data yang digunakan dalam penellitian ini adalah Model Miles and Hubermen, yang terdiri dari 1) Reduksi data, 2) Penyajian data, 3) Verifikasi atau kesimpulan (Sugiyono,. 2013: 246-252).

\section{Reduksi Data}

Reduksi data yaitu proses penyederhanaan dan transformasi data-data kasar yang muncul dari catatan tertulis di lapangan.Mereduksi data berarti merangkum, memilih hal-hal yang pokok, memfokuskan pada hal-hal yang penting, dicari tema dan polanya (Sugiyono, 2013: 201). Dalam penelitian ini yang direduksi adalah hasil catatan lapangan yang kompleks, rumit dan belum bermakna, catatan lapangan 
Analisis Supervisi Klinis Kepala Sekolah di Sekolah Menengah Pertama Islam Terpadu Pondok Pesantren Raudhatul Ulum Sakatiga Indralaya Ogan Ilir

Safri Kandi Ja'far Yazid

berupa hasil observasi, wawancara kepala sekolah dan guru, dokumentasi sekolah dan kegiatan pembelajaran, yang masih semerawut, yang tidak dapat dipahami.

2. Penyajian Data

Sekumpulan informasi tersusun yang memberi kemungkinan adanya penarikan kesimpulan dan pengambilan tindakan.Dalam penelitian kualitatif, penyajian data biasa dilakukan dalam bentuk uraian singkat, bagan, hubungan antarkategori, dan sejenisnya.Yang paling sering digunakan adalah dengan teks yang bersifat naratif (Sugiyono, 2013: 249). Setelah peneliti mampu mereduksi data ke dalam hasil observasi, wawancara, dan dokumentasi, maka langkah selanjutnya adalah mendisplaykan data (penyajian data).Dalam mendisplaykan data, hasil observasi, wawancara, dan dokumentasi disusun ke dalam urutan sehingga strukturnya dapat difahami.

3. Verifikasi atau Penarikan Kesimpulan

Selanjutnya dalam analisis data kualitatif menurut Miles and Huberman adalah penarikan kesimpulan dan verifikasi. Kesimpulan awal yang dikemukakan masih bersifat sementara, dan akan berubah bila tidak ditemukan bukti-bukti yang kuat yang mendukung pada tahap pengumpulan data berikutnya (Sugiyono, 2013: 252). Kesimpulan dalam penelitian kualitatif adalah merupakan temuan baru yang sebelumnya belum pernah ada, temuan dapat berupa deskripsi atau gambaran suatu obyek yang sebelumnya masih remang-remang atau gelap sehingga setelah diteliti menjadi jelas, dapat berupa hubungan kausal atau interaktif, hipotesis atau teori (Sugiyono, 2013: 253). Oleh karena kesimpulan peneliti ditarik berdasarkan data, yang dalam hal ini berupa data yang sudah diolah, maka penarikan kesimpulan dilakukan sejalan dengan cara mengolah data (Arikunto, 2010: 343). Dengan demikian kesimpulan dalam penelitian kualitatif mungkin dapat menjawab rumusan masalah yang dirumuskan sejak awal, tetapi mungkin juga tidak, karena seperti telah dikemukakan bahwa masalah dan rumusan masalah dalam penelitian kualitatif masih bersifat sementara dan akan berkembang setelah penelitian berada di lapangan.

\section{Hasil Penelitian}

1. Analisis Kompetensi Supervisi Klinis Kepala Sekolah di Sekolah Menengah Pertama Islam Terpadu Pondok Pesantren Raudhatul Ulum Sakatiga Indralaya Ogan Ilir.

Pada bagian ini akan dipaparkan data hasil penelitian yang diperoleh dilapangan dengan menggunakan metode wawancara, studi dokumentasi, dan observasi/pengamatan. Deskripsi hasil penelitian dikelompokan menjadi tiga bagian sesuai dengan aspek yang akan diteliti dalam pelaksanaan supervisi oleh kepala sekolah meliputi aspek (1) perencanaan program supervisi(2) pelaksanaan supervisi (3) tindak lanjut hasil supervisi. Berikut adalah deskripsi data hasil penelitian mengenai pelaksanaan supervisi oleh kepala sekolah SMP IT Raudhatul Ulum. 
Volume 4 Nomor 1 Edisi Juni 2019

P-ISSN : 2541-3686

\section{Perencanaan program supervisi}

\section{a. Aspek Penyusunan Program Supervisi}

Kepala sekolah menyusun program supervisi diawali dengan merumuskan tujuan supervisi, menentukan indikator/sasaran supervisi, dan membuat jadwal supervisi, serta mempelajari instrumen supervisi yang akan digunakan dalam supervisi. Dokumen tersebut akan menjadi dasar dan acuan kepala sekolah untuk melaksanakan supervisi. Hal tersebut berdasarkan hasil wawancara yang dilakukan kepada kepala sekolah sebagai berikut:"Saya menyusun program supervisi itu setiap tahun, hal yang dilakukan adalah merumuskan tujuan dan sasaran supervisi, kemudian membuat jadwal dan mempelajari instrumen atau lembar pengamatan yang akan digunakan saat supervisi nanti dilaksanakan."1

Secara umum tujuan supervisi untuk membantu guru meningkatkan kemampuan guru agar menjadi guru yang lebih baik dan professional. Tujuan supervisi dilaksanakan di SMPIT Raudhatul Ulum Sakatiga yaitu: (1) Membantu guru dalam mengembangkan proses pembelajaran supaya tujuan pembelajaran tercapai; (2) Meningkatkan manajemen dan administrasi guru kelas maupun guru mata pelajaran; dan (3) Mengevaluasi kinerja guru dalam rangka pembinaan guru. Hal tersebut berdasarkan tujuan supervisi yang tercantum dalam dokumen program supervisi Tahun pelajaran 2015-2016.

Dasar pertimbangan kepala sekolah dalam membantu guru adalah hasil pengamatan terhadap kinerja guru dan kompetensi guru terkait dengan penguasaan kelas atau metode mengajar, serta hasil penilaian terhadap pembelajaran yang dilakukan guru mulai dari perencanaan pembelajaran hingga penilaian pembelajaran. Hal tersebut berdasarkan hasil wawancara yang dilakukan dengan kepala sekolah sebagai berikut:

“Konsep supervisi yang pertama tujuannya adalah untuk memantau kinerja guru, kemudian apakah mereka mengajar sesuai dengan ketentuan ataukah tidak, semisal dari SKKD nya, materi yang disampaikan ke anak apakah sudah sesuai apa belum. Yang kedua melihat kompetensi guru terkait dengan penguasaan kelas, metode yang digunakan saat mengajar. Dimana dari semua tujuan tersebut pada akhirnya untuk pengembangan prestasi sekolah" ${ }^{2}$

Hasil wawancara menunjukkan bahwa tujuan kepala sekolah melaksanakan supervisi adalah untuk memperbaiki proses pembelajaran yang dilakukan oleh guru. Dasar yang menjadi kepala sekolah dalam memperbaiki proses pembelajaran oleh guru adalah hasil penilaian yang dilakukan oleh kepala sekolah. Penilaian tersebut meliputi penilaian formatif dan objektif yang dilakukan kepala sekolah berdasarkan hasil pemantauan dan pengamatan. Tujuan program supervisi dapat menumbuhkan perbaikan dari proses dan hasil belajar serta untuk

\footnotetext{
${ }^{1}$ Abdul Muhaimin, Kepala Sekolah SMP IT Raudhatul Ulum, (Hasil Hasil Wawancara, Pada Tanggal 7 Februari 2016)

${ }^{2}$ Abdul Muhaimin, Kepala Sekolah SMP IT Raudhatul Ulum Sakatiga Indralaya, (Hasil Wawancara, tgl. 7 Februari 2016)
} 
Analisis Supervisi Klinis Kepala Sekolah di Sekolah Menengah Pertama Islam Terpadu Pondok Pesantren Raudhatul Ulum Sakatiga Indralaya Ogan Ilir

Safri Kandi Ja'far Yazid

mengkoordinasikan maupun menganalisa sutuasi belajar dalam peningkatan kemampuan professional seorang guru, karena jika proses belajar mengajar menigkat mutunya, maka hasil belajar diharapkan juga meningkat.

Kepala sekolah menetapkan sasaran supervisi dengan mencantumkan indikator-indikator yang menjadi perhatian dalam melaksanakan supervisi. Sasaran supervisi yaitu perencanaan pembelajaran yang dilakukan oleh guru, pelaksanaan pembelajaran yang dilakukan guru, dan penilaian/tindak lanjut pembelajaran yang dilakukan oleh guru.

Secara sederhana, sasaran pelaksanaan supervisi adalah proses kegiatan belajar mengajar, penguasaan kelas, pemilihan materi ajar dan metode mengajar yang dilakukan oleh guru. Hal tersebut sebagaimana hasil wawancara dengan kepala sekolah sebagai berikut:“Kelengkapan guru untuk mengajar itu pasti, RPP, silabus, buku kerja dan materi yang akan disampaikan saat dikelas. Kemudian penampilan saat mengajar itu juga dinilai, metodenya dan cara mengajardan penguasaan kelasn. Dan biasanya soal-soal untuk ulangan selalu di cek kemudian saat menyusun laporan hasil belajar siswa juga diteliti sama bapak kepala sekolah." 3

Hasil wawancara tersebut menunjukkan bahwa rencana pelaksanaan pembelajaran (RPP) dan silabus yang disusun guru saat merencanakan pembelajaran menjadi sasaran supervisi. Selain itu, proses guru dalam melaksanakan penilaian pembelajaran yang meliputi soal-soal ulangan dan laporan hasil belajar yang dibuat oleh guru juga menjadi sasaran supervisi.

Selain hasil wawancara di atas peneliti juga melakukan studi observasi untuk mengetahui apa saja sasaran supervisi klinis tersebut, sebagaimana peneliti saksikan bahwa kepla sekolah telah melakukan perencanaan supervisi dapat dibuktikan dengan kepala sekolah menentukan tujuan supervii, dan sasaran supervisi. Yang peneliti dapatkan bahwa sasaran yang terpentinng dalam pelaksanaan supervisi adalag guru, RPP, dan silabus yang dibuat sendiri oleh guru.Berdasarkan studi observasi yang peneliti lakukan di lapangan bahwa dalam proses belajar mengajar di SMPIT Raudhatul Ulum delapan guru yang menjadi narasumber peneliti memang mempersiapkan dan menggunakan perangkat pembelajaran seperti RPP. ${ }^{4}$ Kompetensi supervisi akademik intinya adalah membina guru dalam meningkatkan mutu proses pembelajaran, sasaran supervisi adalah guru dalam melaksanakan proses pembelajaran, yang terdiri dari materi pokok dalam proses pembelajaran, penyusunan silabus dan RPP, pemilihan strategi atau metode pembelajaran, penggunaan media dalam pembelajaran, menilai proses dan hasil pembelajaran serta penilaian tindak lanjut kelas.

Selain merumuskan tujuan dan sasaran supervisi, kepala sekolah selanjutnya membuat jadwal. Jadwal supervisi dibuat oleh kepala sekolah diawal tahun ajaran

\footnotetext{
${ }^{3}$ Susanto, Guru Mata Pelajaran IPS SMP IT Raudhatul Ulum Sakatiga Indralaya, (Hasil Wawancara , tgl. 9 Februari 2016)

${ }^{4}$ Hasil Observasi Lapangan di SMP IT Raudhatul Ulum Sakatiga Indralaya, tgl. 11 Februari 2016
} 
Volume 4 Nomor 1 Edisi Juni 2019

P-ISSN : 2541-3686

baru. Pembagian tugas dan jadwal supervisi yang telah disepakati oleh tim supervisi selanjutnya akan disosialisasikan kepada guru melalui rapat. Dapat diartikan bahwa kepala sekolah membuat jadwal supervisi setelah menentukan tujuan dan sasaran supervisi, dan dari hasil observasi yang peneliti lakukan bahwa kepla sekolah sebelum membuat jadwal supervisi, kepala sekolahh terlebih dahulu melakukan rapat bersama guru, sebagaimana peneliti amati kepala sekolah mengadakan rapat pada saat setelah pelaksanaan upacara di hari senin, yang peneliti amati kepala sekolah memimpin rapat tersebut, dan kepala menyampaikan atau mensosialisasikan tentang supervisi, kepala sekolah menyampaikan bahwa akan dilaksanakan supervisi kepada seluruh guru tanpa terkecuali, hal yang peneliti amati semua guru mernsespon dengan baik dengan akan dilaksanakannya supervisi, selain kepala sekolah menyampaikan rencana supervisi kepala sekolah menyampaikan kepada semua guru untuk mempersiapkan hal yang diperlukan disaat pelaksanaan supervisi, missal RPP dan silabus. Diakhir rapat kepala sekolah mengingatkan kepada seluruh guru tentang kedipsilan dalam waktu datang ke sekolah dan waktu mengajar. ${ }^{5}$

Dari pembahasan di atas peneliti dapat menyimpulkan bahwa pelaksanaan supervisi dilaksanakan satu kali setiap tahun ajaran, dapat dilihat dari jadwal supervisi di SMP IT Raudhatul Ulum ${ }^{6}$ Artinya, guru hanya mendapatkan jadwal supervisi satu kali setiap tahun ajaran. Supervisi dilaksanakan pada pertengahan awal semester genap.Hasil wawancara dan dokumentasi tersebut menunjukkan bahwa kepala sekolah melaksanakan supervisi sebanyak satu kali setiap tahun ajaran. Dari hasil penelitian ini peneliti berpendapat bahwa pelaksanaan supervisi yang sebenarnya harus dilakukan dua kali dalam satu tahun, setiap satu semester harus dilaksanakan supervisi klinis terhadap guru, untuk mengetahui mengapa pelaksanaan supervisi di SMP IT Raudhatul Ulum Sakatiga hanya satu kali dalam satu tahun dapat dillihata dari hasil wawancara dengan kepala sekolah sebagaiberikut "pelaksanaan supervisi di sekolah ini memang hanya satu kali dalam satu tahun, bagi saya pelakasanaan supervisei ini hanya alat pembantu dalam meningkatkan kualitas guru, jadi pelaksanaan supervisi ini cukup satu kali dalam satu tahun" ${ }^{\prime}$, dari penjelassan kepala sekolah tersebut bahwa pelaksanaan supervisi cukup dilakukan satu kali, dan kepala sekolah beranggapan tidak ada bedanya pelaksanaan supervisi dilakukan dua kali atau satu kali dalam satu tahun atau du semester.

\footnotetext{
${ }^{5}$ Hasil Observasi Lapangan di SMP IT Raudhatul Ulum Sakatiga Indralaya, tgl. 11 Februari 2016

${ }^{6}$ Hasil Studi Dokumentasi tata usaha SMP IT Raudhatul Ulum Sakatiga Indralaya T.P 2015-2016

${ }^{7}$ Abdul Muhaimin, Kepala Sekolah SMP IT Raudhatul Ulum Sakatiga Indralaya, (Hasil Wawancara, tgl. 7 Februari 2016)
} 
Analisis Supervisi Klinis Kepala Sekolah di Sekolah Menengah Pertama Islam Terpadu Pondok Pesantren Raudhatul Ulum Sakatiga Indralaya Ogan Ilir

Safri Kandi Ja'far Yazid

\section{Pelaksanaan supervisi}

\section{a. Aspek Penerapan Pendekatan Supervisi}

Ada beberapa pendekatan yang dapat digunakan oleh kepala sekolah, hal ini tentu lebih memudahkan kepala sekolah ketika melaksanakan supervisi. Kepala sekolah atau supervisor dapat memilih pendekatan mana yang digunakan sesuai dengan kondisi, karena setiap pendekatan dalam supervisi memiliki karakteristik yang berbeda. Adapun pendekatan supervisi yang dilakukan adalah pendekatan langsung, tidak langsung.

1) Pendekatan Langsung

Pendekatn langsung adalah pendekatan terhadap masalah dengan secara langsung. Supervisor atau kepala sekolah mengadakan supervisi secara langsung. Pendekatan supervisi langsung yang diterapkan kepala sekolah dapat dilihat melalui hasil wawancara sebagai berikut:"Jadi saat pelaksanaan tentunya mendekati para guru untuk mengetahui kendala apa yang mereka hadapi saat mengajar.Tipikal guru kan berbeda, terkadang ada guru yang mengalami kesulitan tetapi tidak mau mengutarakannya, terkadang juga ada beberapa guru yang menemukan kendala saat mengajar, mereka langsung berkonsultasi." ${ }^{8}$

Berdasarkan hasil wawancara tersebut dapat diketahui kepala sekolah berinisiatif mendekati guru untuk mengetahui kendala yang dialami saat mengajar. Hal tersebut menunjukkan kepala sekolah menggunakan pendekatan langsung.

Hasil wawancara tersebut dapat menunjukkan bahwa kepala sekolah menerapkan pendekatan langsung. Hasil wawancara tersebut dapat diperkuat dengan hasil observasi di lapangan, bahwa pendekatan langsung dapat ditunjukkan dengan kepala sekolah yang aktif mendekati guru untuk mengetahui kendala guru dalam pembelajaran. Seperti yang peneliti amati bahwa kepala sekolah selalu berusaha berkomunikasi dengan semua guru, baik dalam masalah sekolah mapun kendala dalam pembelajaran, dengan adanya usaha kepala sekolah mendekati guru komunikasi akan berjalan lancar, dan guru selalu merasa mendapatkan perhatian dari kepala sekolah, dengan demikian pelaksanaan supervisi tidak akan terasa sebagai beban karena kepala sekolah bukan untuk mencari kesalahan guru. ${ }^{9}$

Dari penjelasan di atas menunjukkan kepala sekolah kadang-kadang melaksankan pendekatan langsung terhadap guru yang sedang melaksanakan proses pembelajaran dikelas tanpa pemberitahuan terlebih dahulu kepada guru yang bersangkutan. Hal tersebut dilakukan kepala sekolah untuk mengetahui kesiapan dan kelengkapan guru dalam mengajar.

2) Pendekatan Tidak Langsung

Selanjutnya, pendekatan tidak langsung ditunjukkan oleh guru yang kadangkadang melaksanakan konsultasi dengan kepala sekolah apabila menemukan kendala dalam proses pembelajaran. Selain itu, hasil observasi menunjukan

${ }^{8}$ Abdul Muhaimin, Kepala Sekolah SMP IT Raudhatul Ulum Sakatiga Indralaya, (Hasil Wawancara, tgl. 10 Januari 2017)

${ }_{9}^{9}$ Hasil Observasi Lapangan di SMPIT Raudhaul Ulum Sakatiga Indrlaya, tgl 7 Agustus 2016 
Volume 4 Nomor 1 Edisi Juni 2019

P-ISSN : 2541-3686

terkadang ada guru yang melakukan konsultasi mengenai kendala saat mengajar. Hal tersebut menunjukkan terkadang ada guru yang aktif menyampaikan kendala yang dialaminya saat mengajar. ${ }^{10}$

Dari hasil obervasi di atas dapat ditarik kesimpulan bahwa pendekatan tidak langsung yang dilakukan ooleh kepala sekolah dapat dilihat dari guru SMPIT Raudhatul Ulum Sakatiga yang secara aktif berinisiatif menyampaikan kendala dan masalah saat melaksanakan proses pembelajaran kepada kepala sekolah untuk selanjutnya guru berharap kepala sekolah dapat memberikan saran maupun solusi.

\section{b. Aspek Penerapan Teknik Supervisi}

\section{1) Teknik Individual}

\section{a) Melihat Kelengkapan Administrasi}

Administrasi supervisi pendidikan merupakan pembinaan yang direncanakan bagi personal dalam proses kerjasama dibidang pendidikan dan peningkatan sumberdaya material dalam rangka perbaikan tujuan pendidikan lebih efektif dan efesien. Kepala sekolah saat rapat terkadang menyampaikan hal-hal yang terkait dengan pembelajaran untuk melihat kelengkapan administrasi guru dalam mengajar. Melihat kelengkapan berkas tersebut dilaksanakan dalam rangka untuk membenahi dan meningkatkan keterampilan guru saat menagajar.

Pernyataan tersebut diperkuat oleh hasil wawancara yang dilakukan kepada ibu Suryani (guru mata pelajaran Bahasa Inggris) yang menjelaskan bahwa:"Sebelum kepala sekolah melakukan supervisi kepada guru, kepala sekolah selalu melihat kelengkapan administrasi, baik dari program tahunan, program semesteran, silabus, RPP dan KKM, dan kepala sekolah selalu melakukan monitoring kepada guru jika kelengkapan administrasi kurang. ${ }^{11}$

Hasil wawancara di atas menunjukkan jika kepala sekolah SMPIT Raudhatul Ulum Sakatiga akan melihat administrasi yang perlu dipersiapkan guru sebelum melaksanakan pembelajaran di kelas. Setelah peneliti melakukan wawancara, peneliti melakukan observasi dengan kegiaatan administrasi guru, dari pengmatan peneliti lakukan memang adanya guru membuat RPP sendiri, tetapi silabus semua guru mengambil atau download dari internet, dengan begitu guru tidak mencontek dalam pembuatan RPP, setelah itu guru menyerahkan RPP dan silbuas tersebut kepada kepala sekolah pada saat sebelum pelaksanaan supervisi, sebagaimana penelit amati Bapak M. Altof memberikan RPP dan silbuas kepada kepala sekolah 10 menit sebelum pelaksanaan supervisi, dan kepala sekolah menerima RPP dan silabus tersebut, setelah itu kepala sekolah membuka RPP tersebut, yang peneliti amati kepala sekolah membaca RPP tersebut tetapi peneliti tidak melihat kepala sekolah membaca silabus tetapi hanya membukanya saja. ${ }^{12}$

${ }^{10}$ Hasil Observasi Lapangan di SMPIT Raudhaul Ulum Sakatiga Indrlaya, tgl 7 Agustus 2016

${ }^{11}$ Suryani, Guru Mata Pelajaran B. Inggris SMP IT Raudhatul Ulum Sakatiga Indralaya (Hasil Wawancara, tgl. 8 Januari 2017)

${ }^{12}$ Hasil Observasi Lapangan di SMP IT Raudhatul Ulum Sakatiga Indralaya, tgl. 11 Februari 2016 
Analisis Supervisi Klinis Kepala Sekolah di Sekolah Menengah Pertama Islam Terpadu Pondok Pesantren Raudhatul Ulum Sakatiga Indralaya Ogan Ilir

Safri Kandi Ja'far Yazid

Dari penjelasann di atas bahwa kepala sekolah melakukan administrasi pendidikan, Jika ada kekurangan dalam administrasi kepala sekolah melakukan monitoring kepada guru. Penjelasan tersebut dapat dilihat dari hasil melihat kelengkapan administrasi yang terlampir. ${ }^{13}$

\section{b) Kunjungan Kelas}

Teknik lainnya yang digunakan adalah kunjungan kelas, yaitu kepala sekolah melakukan pengamatan terhadap guru yang sedang mengajar. Hal tersebut sebagaimana hasil wawancara dengan kepala sekolah sebagai berikut:

"Jadi seperti yang saya jelaskan di depan tadi, kalau kami selalu menyampaikan program kami saat rapat dewan guru, kemudian kita sepakati bersama mengenai jadwal kunjungan kelas pada saat guru mengajar. Kemudian saat dikelas saya memperhatikan guru saat mengajar selama dua jam pelajaran, saya catat mengenai kekurangan ataupun kelebihan guru tersebut, dan kemudian hari kita panggil guru tersebut untuk menyampaikan hasil kunjungan kelas saya tersebut. Selain kunjungan kelas, tentunya juga kami kadang melaksanakan rapat dengan para dewan guru untuk membahas terkait pembelajaran." 14

Teknik supervisi yang diterapkan kepala sekolah saat melaksankan supervisi dijelaskan lebih lanjut bapak Ainul Wafa(guru mata pelajaran Nahwu) yang menjelaskan bahwa:"Yang pertama setelah disosialisasikan tentang supervisi, selanjutnya pelaksanaan supervisi atau kunjungan kelas, bapak kepala sekolah masuk kelas dan mengamati guru selama duajam pelajaran, lalu sehabis dua jam pelajaran dihari yangsama ataukah berbeda, kami dipanggil untuk dikasih lihat catatan bapak kepala sekolah. Setelah itu bapak kepala sekolah akan memberi arahan ataupunperbaikan mana yang kurang dan perlu perbaikan." 15

Hasil wawancara tersebut menunjukkan bahwa kepala sekolah saat melaksankan kunjungan kelas akan mengamati guru saat mengajar selama dua jam pelajaran. Selama pengamatan dilaksankan, kepala sekolah akan melakukan pencatatan terkait dengan penampilan guru saat mengajar mulai dari pembukaan hingga penutup.

Untuk memperkuat hasil wawancara di atas dapat dilihat dari hasil observasi di lapangan, bahwa benar kepala sekolah melakukan kunjungan kelas terhadap guru yang telah mendapatkan jadwal supervisi, pada saat pelaksanaan supervisi kepala sekolah melakukan pengamatan dan penilaian terhadap guru sesuai dengan instrumen supervisi kegiatana belajar. ${ }^{16}$ Hasil wawancara dan observasi di lapangan diperkuat dengan hasil dokumentasi penilaian supervisi yang terlampir. ${ }^{17}$

${ }^{13}$ Hasil Studi Dokumentasi tata usaha SMP IT Raudhatul Ulum Sakatiga Indralaya T.P 2015-2016

${ }^{14}$ Abdul Muhaimin, Kepala Sekolah SMP IT Raudhatul Ulum, (Hasil Hasil Wawancara, Pada Tanggal 7 Februari 2017)

${ }^{15}$ Ainul Wafa, Guru Mata Pelajaran Nahwu di SMP IT Raudhatul Ulum Sakatiga Indralaya, (Hasil Wawancara , tgl. 11 Februari 2017)

${ }^{16}$ Hasil Observasi Lapangan di SMPIT Raudhaul Ulum Sakatiga Indrlaya, tgl 13 Agustus 2016

${ }^{17}$ Hasil Studi Dokumentasi tata usaha SMP IT Raudhatul Ulum Sakatiga Indralaya T.P 2015-2016 
Hasil wawancara, observasi dan dokumentasi menunjukkan pelaksanaan supervisi dimulai dengan sosialisasi kepada guru mengenai tujuan dan jadwal supervisi. Kepala sekolah melakukan kunjungan kelas sesuai dengan jadwal yang telah disepakati. Hasil temuan saat kunjungan kelas akan didiskusikan antara guru dengan kepala sekolah dan selanjutnya akan dilaksanakan tindak lanjut. Teknik kunjungan kelas yang dilakukan kepala sekolah yaitu dengan melakukan penilaian kepada guru dengan memberi skor pada setiap proses yang dilakukan oleh guru baik sebelum hingga proses penilaian pembelajaran.

\section{c) Percakapan Pribadi}

Hasil pengamatan dilakukan peneliti untuk mengetahui interaksi antara kepala sekolah dengan para guru. Pengamatan dilakukan saat jam istirahat, hasil pengamatan menunjukkan beberapa guru saling bertukar pendapat dan membahas keadaan salah satu kelas dan membahas beberapa masalah yang dihadapi guru untuk mencari solusi dari masalah yang dihadapi tersebut, sesekali para guru menanyakan cara mengatasi masalah yang ada kepada kepala sekolah dan kepada para guru..$^{18}$

\section{2) Teknik Kelompok}

\section{a) Rapat Kepala Sekolah dan Guru}

Kepala sekolah menerapkan beberapa teknik supervisi saat melaksanakan supervisi. Salah satu teknik yang digunakan adalah rapat antara kepala sekolah dengan guru. Rapat dilaksanakan untuk membahas hal yang terkait dengan pelaksanaan supervisi seperti sosialisasi jadwal supervisi. Selain itu, rapat dilaksanakan kepala sekolah untuk membahas hal yang berhubungan dengan pembelajaran. Kepala sekolah mengagendakan briefing setiap Hari Senin setelah pelaksanaan upacara bendera, rapat dilaksanakan dengan memanfaatkan sisa jam pelajaran apabila upacara bendera selesai lebih awal.Narasumber menyampaikan hal senada mengenai penerapan teknik beserta prosedur pelaksanaan supervisi di SMP IT Raudhatul Ulum melalui hasil wawancara bapak Slamet Riadi (guru mata pelajaran Fiqih) yang menjelaskan bahwa: "Rapat sekolah sering dilakukan oleh kepala sekolah pada hari senin, teknik rapat ini digunakan oleh kepala sekolah unntuk menyampaikan tentang supervisi yang akan dilaksanakan, seperti sosialisasi jadwal supervisi." 19

Selama peneliti berada di tempat penelitian, peneliti melihat kepala sekolah melakukan rapat bersama guru. Dalam ini kepala sekolah selalu menyampaikan tentang keutamaan guru dalam pembelajaran, dan kepala sekoah berharap kepada semua guru agar dapat mematuhi semua peraturan yang ada dikelas, seperti tepat waktu dalam datang kesekolah dan waktu jam pelajaran, dan guru harus selalu mempersiapkan administrasi guru, seperti RPP dan silabus, dengan hasil observasi ini bahwa kepala sekolah memamfaatkan rapat sekolah dalam mensupervisi guru

\footnotetext{
${ }^{18}$ Hasil Observasi Lapangan di SMPIT Raudhaul Ulum Sakatiga Indrlaya, tgl 14 Agustus 2016

${ }^{19}$ M. Slamet Arif, Guru Mata Pelajaran Al-Qur'an di SMP IT Raudhatul Ulum,(Hasil Wawancara, pada tanggal 9 Februari 2016)
} 
Analisis Supervisi Klinis Kepala Sekolah di Sekolah Menengah Pertama Islam Terpadu Pondok Pesantren Raudhatul Ulum Sakatiga Indralaya Ogan Ilir

Safri Kandi Ja'far Yazid

secar menyeuruh. ${ }^{20}$ Dapat disimpulkan bahwa kepala sekolah telah menggunakan teknik rapat kepala sekolah dan guru dengan baik. Tujuan utamanya adalah untuk memperbaiki kualitas guru dalam melaksanakan tugas sebagai guru menjadi guru yang porofesional dan tercapainya tujuan supervisi yang dilakukan oleh kepala sekolah.

\section{Penindak Lanjuti Hasil Supervisi}

\section{a) Menganalisis dan Mengevaluasi Hasil Supervisi}

Kepala sekolah melakukan analisis hasil supervisi untuk mengetahui langkah apa yang akan dilakukan selanjutnya terhadap guru. Selain itu, hasil analisis akan dijadikan sebagai bahan pertimbangan kepala sekolah untuk melakukan evaluasi terhadap guru. Hasil wawancara yang menunjukkan siapa yang terlibat dan bagaimana kepala sekolah dalam melakukan analisis hasil supervisi disampaikan oleh kepala sekolah, yang menyatakan bahwa:"Yang terlibat seperti yang saya sampaikan tadi adalah guru dan saya sendiri kami komunikasikan bersama dan analisis bersama dan kami cari solusinya pun juga bersama-sama. Sedangkan untuk masalah yang sifatnya umum, kami bahas melalui rapat dewan guru," 21

Hasil wawancara lain mengenai analisis dan evaluasi hasil supervisi diungkapkan oleh bapak Afrizal (guru mata pelajaran TIK) yang menjelaskan bahwa: "Proses selanjutnya itu nanti akan dipanggil untuk briefing sama bapak kepala sekolah, bapak kepala sekolah akan menyampaikan apa yang beliau amati saat guru mengajar dikelas. Nanti akan dibahas bersama antara bapak kepala sekolah dengan guru yang bersangkutan, dan nanti akan dibahas mengenai tindak lanjut apa yang akan dilaksanakannya."22

Beberapa hasil wawancara tersebut menunjukkan analisis hasil supervisi dilakukan kepala sekolah bersama guru dengan menganalisa secara bersama-sama hasil supervisi yang dilaksanakan. Hasil suprvisi akademik yang dimaksud adalah temuan-temuan kepala sekolah sewaktu melaksanakan pengamatan/monitoring dan pemantauan saat kunjungan atau observasi kelas. Analisis dan evaluasi hasil supervisi dilakukan antara guru yang di supervisi dengan kepala sekolah. Selanjutnya, terkait temuan-temuan masalah yang sifatnya umum, analisis dan evaluasi akan dilakukan melalui rapat antara kepala sekolah dengan para guru.

Analisis dan evaluasi hasil supervisi adalah tahapan yang dilaksanakan kepala sekolah setelah rangkaian pelaksanaan supervisi selesai dilaksanakan. Hasil penelitian mengenai analisis dan evaluasi hasil supervisi dapat dilihat melalui hasil wawancara dengan kepala sekolah sebagai berikut:“Memperlihatkan catatan-catatan yang saya temukan kepada guru, dan kami bahas bersama sambil

\footnotetext{
${ }^{20}$ Hasil Observasi Lapangan di SMPIT Raudhaul Ulum Sakatiga Indrlaya, tgl 15 Agustus 2016

${ }^{21}$ Abdul Muhaimin, Kepala Sekolah SMP IT Raudhatul Ulum, (Hasil Hasil Wawancara, Pada Tanggal 7 Februari 2017)

${ }^{22}$ Afrizal, Guru Mata Pelajaran TIK SMP IT Raudhatul Ulum, (Hasil Wawancara , tgl. 15 Februari 2016)
} 
P-ISSN : 2541-3686

menggalipengakuan dari bapak ibu guru tentang kesulitan apa saja yangdihadapi." 23

Hasil wawancara tersebut menunjukkan kepala sekolah akan memperlihatkan temuan-temuan berupa catatan-catatan sewaktu kepala sekolah melakukan monitoring atau kunjungan kelas untuk mengamati penampilan guru saat melaksanakan proses pembelajaran. Hasil temuan atau catatan kepala sekolah tersebut selanjutnya akan dibahas bersama dengan guru yang bersangkutan. Selain itu, kepala sekolah mencoba menggali kesulitan yang dialami guru saat proses pemebelajaran.

Berdasarkan hasil wawancara tersebut, hasil analisis yang dilakukan kepala sekolah bersama guru selanjutnya akan menjadi bahan pertimbangan atau dasar kepala sekolah untuk merekomendasikan tindak lanjut yang perlu dilaksanakan terhadap guru. Hasil wawancara juga menunjukkan jika analisis hasil monitoring saat kunjungan kelas dan hasil supervisi akan dibahas melalui rapat antara kepala sekolah dengan guru untuk membahas mengenai tindak lanjut apa yang perlu dilaksanakan.

\section{b) Melaporkan Hasil Supervisi}

Selain menganalisis dan mengevaluasi hasil supervisi, kepala sekolah melaporkan hasil supervisi kepada pengawas.Hal tersebut sebagaimana hasil wawancara dengan kepala sekolah sebagai berikut:“Setiap supervisi yang kami laksanakan pasti kamisampaikan kepada pengawas di dinas. Karena instrument yang kamigunakan pun juga dari dinas. Sedangkan untuk yayasan sifatnyahanya laporan secara lisan mengenai perkembangan ataupun keadaansekolah pada saat rapat dengan yayasan." ${ }^{24}$

Hasil wawancara lain mengenai pelaporan hasil supervisi disampaikan oleh bapak Afrizal(guru mata pelajaran Teknologi Ilmu Komputer) yang menjelasskan bahwa: "Setelah kepala sekolah melakukan supervisi, kepala sekolah menyampaikan kepada guru bahwa hasil supervisi akan dilaporkan kepada dinas, dan yayasan pondok pesantren." 25

Hasil wawancara di atas menunjukkan hasil supervisi dilaporkan kepada pengawas, laporan itu disampaikan untuk melaporkan pelaksanaan supervisi dan hasil supervisi yang telah dilaksanakan sekolah. Selain itu, hasil supervisi dilaporkan kepada yayasan Pondok Pesantren Raudhatul Ulum Sakatiga saat rapat dengan yayasan dilaksanakan.

Hasil temuan yang sifatnya umum akan disampaikan melalui rapat antara kepala sekolah dengan guru. Kepala sekolah setelah melakukan analisis dan evaluasi hasil supervisi selanjutnya akan melaporkan hasil supervisi kepada pengawas. Hasil wawancara menunjukkan laporan hasil supervisi di SMP IT

${ }^{23}$ Abdul Muhaimin, Kepala Sekolah SMP IT Raudhatul Ulum, (Hasil Hasil Wawancara, Pada Tanggal 7 Februari 2016)

${ }^{24}$ Abdul Muhaimin, Kepala Sekolah SMP IT Raudhatul Ulum Sakatiga Indralaya, (Hasil Wawancara, tgl. 10 Januari 2017)

${ }^{25}$ Afrizal, Guru Mata Pelajaran TIK, (Hasil Hasil Wawancara, Pada Tanggal 7 Februari 2017) 
Analisis Supervisi Klinis Kepala Sekolah di Sekolah Menengah Pertama Islam Terpadu Pondok Pesantren Raudhatul Ulum Sakatiga Indralaya Ogan Ilir

Safri Kandi Ja'far Yazid

Raudhatul Ulum dilaporkan kepada pengawas dalam bentuk laporan tertulis disertai lampiran hasil penilaian kepala sekolah sewaktu melaksanakan pengamatan terhadap guru. Selain itu, hasil supervisi disampaikan kepada yayasan apabila rapat antara sekolah dengan yayasan dilaksanakan, laporan yang dilakukan kepada yayasan dilakukan secara tidak tertulis.

\section{Simpulan}

Berdasarkan analisa data pada bab sebelumnya maka dapat diambil beberapa kesimpulan sebagai berikut: kompetensi supervisi yang dilakukan di SMP IT Raudhatul Ulum Sakatiga telah berjalan baik sesuai dengan tujuan. Kompetensi supervisi sesuai dengan prinsip, teknik, pendekatan dan melakukan tindak lanjut dari hasil supervisi yang dilakukan. 
RAUDHAH Proud To Be Professionals Jurnal Tarbiyah)damiyah

Volume 4 Nomor 1 Edisi Juni 2019

P-ISSN : 2541-3686

\section{DAFTAR PUSTAKA}

Ara Hidayat dan Imam Machali. 2012. Pengelolaan Pendidikan, (Konsep, Prinsip, dan Aplikasi Dalam Mengelola Sekolah dan Madrasah). Bandung: Kaukaba

Aravik, Havis, 2018. Pengantar Studi Islam, Palembang: Rafah Press.

Arikunto, Suharsimi.2010. Manajemen Penelitian. Jakarta: Rineka Cipta

Basri, Hasan.2012. Kapita Selekta Pendidikan. Bandung: CV. Pustaka Setia

Burhanuddin. 1994. Analisis Administrasi Manajemen dan Kepemimpinan Pendidikan,. Jakarta: PT. Bumi Aksara

Cholid Narbuko dan Abu Achmadi. 2012. Metodologi Penelitian,Cet. Ke-12. Jakarta: PT Bumi Aksara

Daryanto dan Mohammad Farid.2013. Konsep Dasar Manajemen Pendidikan di Sekolah, Yogyakarta: Penerbit Gava Media

Daryanto, M Farid. 2013. Konsep Dasar Manajemen Pendidikan di Sekolah. Yogyakarta, Gava Media

Daryanto. 2013. Administrasi dan Manajemen Sekolah. Jakarta: PT. Rineka Cipta

Departemen Pendidikan Nasional, Kamus Besar Bahasa Indonesia, edisi ke-4. Jakarta: PT Gramedia Pustaka Utama, 2013

Djunaidi Ghony dan Fauzan Almanshur.2012. Metodologi Penelitian Kualitatif. Jogjakarta: Ar-Ruzz Media.

E. Mulyasa.2000. Menajemen Berbasis Sekolah. Bandung: PT. Remaja Rosdakarya

E. Mulyasa.2009. Menajadi Kepala Sekolah Profesional. Bandung: PT. Remaja Rosdakarya

Gultom, Syawal.20111. Buku Kerja Pengawas Sekolah, cet. ke-II. Jakarta: PPTK Badan PSDM dan PMP Kementrian Pendidika Nasional

Ibrahim Bafadal.2005. Dasar-dasar Manajemen dan Supervisi. Jakarta: Bumi Askara

Imran, Ali. Tafsir. Perspektif Manajemen Pendidikan Berbasis Sekolah. Jogyakarta: Universitas Negri Malang

Irham Fahmi.2013. Manajemen Kepemimpinan, Teori dan Aplikasi. Bandung: Alfabeta

Jerry H. Makawimbang.2011. Supervisi dan Peningkatan Mutu Pendidikan. Bandung: Alfabeta

Kusnandar.2011. Guru Profesional. Jakarta: Rajawali Pers

Lantip Diat Prasojo dan Sudiyono.2011. Supervisi pendidikan, cet I.Yogyakarta: Gava Media 
Analisis Supervisi Klinis Kepala Sekolah di Sekolah Menengah Pertama Islam Terpadu Pondok Pesantren Raudhatul Ulum Sakatiga Indralaya Ogan Ilir

Safri Kandi Ja'far Yazid

M. Amin Thaib. 2005. Standar Supervisi dan Evaluasi Pendidikan Pada Madrasah, (Jakarta: Departemen Agam RI

Mukhtar dan Iskandar.2009. Orientasi Baru Supervisi Pendidika,Cet. I. Jakarta: Gaung Persada Press

Nana Sudjana, dkk.2012. Penelitian dan Penilaian Pendidikan. Bandung: Sinar Baru Algensindo

Ngalim Purwanto. 2003. Administrasi dan Supervisi Pendidikan. Bandung: Remaja Rosdakarya

Pidarta, Made.2009. Supervisi Pendidikan Kontekstual. Jakarta: Rineka Cipta

Piet A. Sahertian. 2006. Konsep Dasar dan Teknik Supervisi Pendidikan, (Jakarta: PT. Rineka Cipta

Rohita.2010. Manajemen Sekolah (Teori Dasar dan Praktik), cetakan ketiga. Bandung: PT. Refika Aditama

Rusman.2013. Belajar dan Pembelajaran Berbasis Komputer, (Mengembangkan Profesionalisme Guru Abad 21). Bandung: Alfabeta

Saebani, Beni Ahmad. 2008. Metode Penelitian. Bandung: Pustaka Setia.

Sugiyono.2013. Metode Penelitian Kuantitatif Kualitatif dan $R$ dan D, Cet. Ke-19. Bandung: Alfabeta

Suhardan, Dadang. 2010. Saebani. Supervisi Profesional, Layanan Dalam Meningkatkan Mutu Pembelajaran di Era Otonomi Daerah, cet. Ke-3. Bandung: Alfabeta

Sujipto dan Raflis Kosasi.2009. Profesi Keguruan. Jakarta: Rineka Cipta

Suryobroto.2004. Manajemen Pendidikan di Sekolah. Bandung: Alfabeta

Undang-undang dan Peraturan Pemerintah Tentang Pendidikan, (Depag RI:2006)

Undang-undang Guru dan Dosen (UU RI NO. 14 Th. 2005), cet. Ke 7, (Jakarta: Sinar Grafika, 2014)

Undang-undang SISDIKNAS (UU RI No. 20 Th. 2003), (Jakarta: Sinar Grafika, 2011)

Zainal Aqib dan Ehlam Rohmanto.2008. Profesionalisme Guru dan Pengawasan Sekolah, Cet. Ke-II. Bandung: CP. Yrama Widya. 